\title{
Assessment of a Brazilian public policy intervention to address schistosomiasis in Pernambuco state: the SANAR program, 2011-2014
}

Luiz Augusto Facchini ${ }^{1,2}$, Bruno Pereira Nunes ${ }^{2^{*}}$ (D) Eronildo Felisberto ${ }^{3}$, José Alexandre Menezes da Silva ${ }^{4}$, Jarbas Barbosa da Silva Junior ${ }^{5}$ and Elaine Tomasi ${ }^{1}$

\begin{abstract}
Background: Brazil is an endemic country for schistosomiasis in the Latin American and Caribbean countries. Pernambuco is a higher-endemic Brazilian state among the 19 states reporting the disease in the country; schistosomiasis affects 102 (55\%) of its 185 municipalities. Our objective was to evaluate the effectiveness of the treatment cycles of the SANAR Program (Plan to Reduce and Eliminate Neglected Diseases) in Pernambuco State in Northeast Brazil.

Methods: A cross-sectional population-based study was conducted in 2014 via a household survey in 117 hyperendemic locations in the state of Pernambuco. We compared the schistosomiasis prevalence rates in hyperendemic locations, aggregated by geographical region, before and after the intervention. The dependent variable was a positive stool test result by the Kato-Katz method, and the main exposure variable was the number of treatment cycles (one/two). The covariables were the regions of the state and socioenvironmental, socioeconomic, demographic and behavioral characteristics.

Results: In all, 12,969 individuals were interviewed, 8932 of whom had stool tests. Of these, 4969 (55.6\%) underwent two cycles of collective treatment. Changes in the environmental conditions since 2011 were minimal. Comparison before (2011) and after (2014) treatment showed an average schistosomiasis prevalence of 18.6\%, decreasing to $4.1 \%$ and $2.0 \%$ in locations with one and two treatment cycles, respectively. In 2014, the highest schistosomiasis prevalence was found in the forest area (2.8\%), while the lowest was found in the northern region (1.2\%) of the state. The adjusted analysis showed a lower occurrence of schistosomiasis in individuals living in areas with two treatment cycles than in individuals from areas with just one cycle (PR 0.65, 95\% Cl: 0.47-0.89).

Conclusions: The political decision made in Pernambuco to implement the SANAR Program in 2011 greatly impacted the burden of schistosomiasis. This program was effective in reducing the occurrence of schistosomiasis in hyperendemic areas in Pernambuco, with a stronger response in areas with two cycles of collective treatment.
\end{abstract}

Keywords: Schistosomiasis, Collective treatment, Parasitic diseases, Prevalence, Health policy, Brazil

\footnotetext{
* Correspondence: nunesbp@gmail.com

${ }^{2}$ Programa de Pós-Graduação em Enfermagem, Universidade Federal de Pelotas, Rua Gomes Carneiro, 1, Campus ANGLO, Centro, Pelotas, RS CEP: 96010-610, Brazil

Full list of author information is available at the end of the article
}

(c) The Author(s). 2018 Open Access This article is distributed under the terms of the Creative Commons Attribution 4.0 International License (http://creativecommons.org/licenses/by/4.0/), which permits unrestricted use, distribution, and reproduction in any medium, provided you give appropriate credit to the original author(s) and the source, provide a link to the Creative Commons license, and indicate if changes were made. The Creative Commons Public Domain Dedication waiver (http://creativecommons.org/publicdomain/zero/1.0/) applies to the data made available in this article, unless otherwise stated. 


\section{Background}

Schistosomiasis is an infectious disease caused by digenetic trematodes of the Schistosoma genus. In 2015, schistosomiasis affected approximately 250 million people worldwide [1]. The disease is transmitted by Schistosoma mansoni in the Region of the Americas, and Brazil and Venezuela present the highest endemicity [2,3]. Between 2.5 and 6 million people are currently estimated to be infected with S. mansoni [4], and 700-800 deaths are reported annually in 19 Brazilian endemic states $[5,6]$. A recent systematic review and meta-analysis reported that the prevalence of $S$. mansoni infection in Brazil varied widely, from 0.1 to $73.1 \%$, based on the Kato-Katz technique [7].

Pernambuco is one of the states where schistosomiasis is endemic; in Pernambuco, schistosomiasis affects 102 (55\%) of the 185 municipalities, with regional differences [8], and between 10 and $50 \%$ of test results are positive $[9,10]$. The death and hospitalization rates related to schistosomiasis are significantly higher in Pernambuco than in other Brazilian states [11]. The low socioeconomic level and scarcity of knowledge about the problem of schistosomiasis increase the transmission of the disease, particularly among children and adults, because of participation in recreational and occupational activities [12].

In addition to involving improved sanitation conditions and treated drinking water availability $[10,13]$, the control of schistosomiasis involves early diagnosis, timely treatment, surveillance and educational actions [14]. In endemic areas with positivity rates equal to or greater than $10 \%$, schistosomiasis control using praziquantel is recommended by means of large-scale treatment of the population. The strategy of treating all individuals greater than two years of age [15] is associated with a decrease in the worldwide schistosomiasis occurrence $[15,16]$.

A single dose of medication is considered an effective collective treatment and is a safe and low-cost strategy for controlling all forms of schistosomiasis [17]. In 2014, more than 60 million people were treated for schistosomiasis worldwide [18].

In keeping with World Health Organization (WHO) proposals, in 2011, Brazil launched its Integrated Strategic Action Plan for the Elimination of Neglected Diseases [4]. In cooperation with state- and municipallevel health service managers, the plan proposes the active searching for and timely treatment of cases, considering, when indicated, collective treatment interventions in locations with positive test results in more than $25 \%$ of the population [14]. In 2011, the Pernambuco State Health Department launched the SANAR Program to reduce and/or eliminate the following neglected diseases: schistosomiasis, tuberculosis, leprosy, Chagas disease, leishmaniasis, filariasis, geohelminthiases and trachoma. SANAR is the first initiative of the integrated plan at the state level to develop a specific program for combating schistosomiasis by including collective treatment. The main integrated SANAR actions were community education and environmental assessment in hyperendemic areas for schistosomiasis [10, 19], supplemented by household collective treatment. At the management level, the program established guidelines, goals and indicators that were routinely monitored as part of the priority actions of the Pernambuco State Government $[20,21]$; these parameters were associated with the training of health workers, particularly primary health care teams, community health workers, and personnel from endemic control, health surveillance, information systems, and laboratory organizations [22].

In contrast with the national reference and in line with the WHO recommendations [15], the political decision made in Pernambuco was to maximize the effectiveness of intervention; to this end, the Pernambuco State Health Department adopted collective treatment for areas where the schistosomiasis prevalence in the population was greater than $10 \%$. This intervention was integrated with selective treatment involving family health teams that was made available also in endemic areas with prevalence rates below $10 \%$ [23].

Given the social relevance of the SANAR Program to reduce and eliminate schistosomiasis as a neglected disease, this article aims to evaluate the effectiveness of this program according to the collective treatment cycles. To contextualize the relevance of the findings of the effectiveness study, we previously assessed the trends for disease positivity, treatment, hospitalization and mortality during the period 2010-2014 both in Pernambuco and in Brazil.

\section{Methods}

Schistosomiasis trends in Pernambuco and in Brazil

The trend study was conducted based on secondary data routinely collected in Brazil and obtained from health information systems. The data on the positivity of tests performed to confirm schistosomiasis and on the treatment of confirmed cases were provided by the Information System for Notifiable Diseases (SINAN), the data on hospitalization owing to schistosomiasis were obtained from the Hospital Information System (SIH-SUS), and the data on deaths due to schistosomiasis (B65 ICD-10) were obtained from the Mortality Information System (SIM). The data in the three databases were both for the state of Pernambuco and for the country of Brazil for the same period: 2010-2014.

\section{SANAR program: selection of locations for collective treatment interventions}

Based on the Schistosomiasis Control Program Information System (SIS-PCE/SES-PE), a total of 119 hyperendemic 
locations in rural and urban areas of 30 priority municipalities were identified in the state of Pernambuco for the years 2010 and 2011. The municipalities that had a mean prevalence of $10 \%$ or more between 2005 and 2010 were included in the program [23]. In each endemic municipality, all locations with a schistosomiasis prevalence greater than or equal to $10 \%$ were included [24].

In the 119 locations selected, three cycles of collective treatment using chemotherapy were planned to take place, with a minimum planned coverage of $80 \%$ of the target population. In 2012 and 2013, 61 (52.1\%) locations received one treatment cycle and 56 (47.9\%) received two cycles. Approximately $70 \%$ of the locations had a mean coverage greater than $70 \%$ (lower: southern $=67 \%$; higher: metropolitan zone $=$ $79 \%$ ), with a median coverage of $79 \%$.

Praziquantel manufactured by Farmanguinhos was used for treatment at a dose of $50 \mathrm{mg}$ per kilo of body weight $(\mathrm{mg} / \mathrm{kg})$ for people over 15 years old and $60 \mathrm{mg} / \mathrm{kg}$ for children between two and 15 years old. The recommended dosage is different because of differences in the metabolism of adults and children. Praziquantel was provided in tablet format and administered orally in a single dose. Adverse effects are slight, and there is no evidence that praziquantel produces serious toxic lesions of the liver or other organs $[2,15,24]$.

\section{Effectiveness evaluation survey}

In September and October 2014, a cross-sectional population-based study was conducted via a household survey to evaluate the performance of the SANAR program in relation to schistosomiasis in 117 hyperendemic locations. The survey compared the schistosomiasis prevalence rates before and after the intervention in hyperendemic locations aggregated by geographical region. The sampling process selected a representative sample in all regions with endemic areas stratified by the number of collective treatments performed. A starting point was chosen in each locality, and from this starting point, a systematic sample of households was included. The quota was proportional to the size of the locality. The higher/ lower the population of the locality, the higher/lower was the number of households selected. The number itself was based on this proportionality and on the final intended sample size. The final sample population was 11,842 . All individuals in each household aged over two years old were included. Pregnant women were excluded.

The data were collected by health surveillance personnel from the State Health Department of Pernambuco using handheld computers following one week of training. If an eligible family member was absent, the data for that individual were obtained from a key informant. At the same time as the data collection, marked plastic containers were provided for the collection of stool samples from the household the next day. The samples were kept on ice in Styrofoam coolers. On the third day, the coolers were delivered to the laboratory, where they were stored in refrigerators until the preparation and reading of microscope slides. Laboratory analysis took place between the first week of September and the end of October 2014. Before being read under a microscope, the slides were prepared by mid-level professional staff at the schistosomiasis laboratory of the municipality of Jaboatão dos Guararapes-PE. The Kato-Katz method was used [25]. This predominant method for detecting $S$. mansoni eggs is relatively straightforward, inexpensive and highly specific [26-29]. Valid stool samples were those for which the stool quantity was sufficient to allow the sample to be processed via the Kato-Katz method. Some of the collection containers delivered had no stool, only a small amount of stool, or stool of a liquid or pasty consistency, which prevented processing for slide preparation. The test results were read by biologists from the State Laboratory of Public Health working for the schistosomiasis control program. The results were recorded on the epidemiological surveillance field form and sent for processing at the State Health Department. After input, copies of the forms were sent to the municipalities to be entered into the SISPCE and to allow the treatment of positive cases.

The dependent variable was a positive stool test result for Manson's schistosomiasis, and the main exposure variable was the number of treatment cycles (one/two). The other exposure variables were the following: "region of the state" (northern (Agreste Setentrional)/metropolitan/southern (Agreste Meridional)/forest area (Zona da Mata)); "zone of residence"; the presence of open drainage ditches/sewers; "positive house flooding status"; "economic status" according to the Brazilian Association of Studies and Research (B and C/D/E); "sex" (female/ male); "age" (<5/5-14 years/15-44 years/45 years or over); "skin color or race" (Caucasian, Afro-Brazilian, Asian, Mixed/Pardo Brazilian, Amerindian); "cohabitation status"; "contact with river water"; "contact with water from open drainage ditches/sewers"; "walking barefoot in the street"; and "schistosomiasis occurrence at some time in life".

The raw and adjusted analyses were performed using Poisson regression with robust variance adjustment [30]. The adjusted analysis aimed to evaluate the effect of the number of treatment cycles on the occurrence of schistosomiasis. To this end, a hierarchical analysis model was used with the aim of determining which variables influenced the association. The adjusted analyses comprised four levels (adjustment 1: "region of the state" and "zone of residence"; adjustment 2: "positive house flooding status" and "economic status"; adjustment 3: "sex", "age" and "skin color"; adjustment 4: "contact with 
river water" and "schistosomiasis occurrence at some time in life").

\section{Results}

Schistosomiasis trends in Pernambuco and in Brazil

Almost 100,000 and 1,382,785 tests to assess for schistosomiasis positivity were performed in Pernambuco and Brazil, respectively, in 2010; 256,809 and 814,905 tests were performed in Pernambuco and Brazil, respectively, in 2014. Schistosomiasis positivity was $8.31 \%$ in 2010 and $3.39 \%$ in 2014 in the state of Pernambuco (during these same years, the positivity decreased from 5.02 to $4.07 \%$ in Brazil). In Pernambuco, the proportion of individuals with positive test results who were treated increased, while in Brazil, this proportion decreased. The rate of hospitalization from schistosomiasis (per 100,000 inhabitants) decreased in both Pernambuco and Brazil. The schistosomiasis mortality rate in Pernambuco decreased from 2.23 (per 100,000 inhabitants) in 2010 to 1.51 in 2014. The total mortality rate for Brazil was 0.27 in 2010 and 0.24 in 2014 (Please see Table 1).

\section{Effectiveness evaluation survey}

A total of 12,969 individuals were interviewed; valid stool samples were collected for evaluation from 8932
(68.9\%) of these. Among the infected study subjects $(n=197)$, the mean number of eggs per slide was 7.9 (189.3 per gram), the median was 2 per slide (48 per gram), the interquartile interval per slide was 1-6 (24-144 per gram), and $52.3 \%$ of the subjects presented 1 or 2 eggs per slide by examination (more than 48 eggs per gram). A total of 4969 (55.6\%) of the individuals underwent two treatment cycles. The forest area (Zona da Mata) region had the highest proportion of interviewees (31.7\%). Half of the interviewed individuals lived in the urban zone. A total of $41.2 \%$ of the individuals lived in locations with open drainage ditches/ sewers that had been corrected in fewer than $3 \%$ of these locations. Water usually flooded the houses of $11.2 \%$ of the individuals, while $27.5 \%$ reported that there had never been flooding where they lived. Only $3.1 \%$ stated that the flooding situation had improved since 2011. The majority of the interviewees were of economic status D (58.8\%). Half of the sample was female, and half was aged 15-44. The most commonly reported skin color was brown (62.3\%), and $45.9 \%$ reported having a partner. Almost one-third reported having current contact with river water (28.7\%) and with water from open drainage ditches/sewers (33.4\%). Less than $15.0 \%$ stated that they always walked barefoot in the street, and $61.9 \%$ stated that they never did

Table 1 Indicators of schistosomiasis positivity, hospitalization and mortality in Pernambuco and Brazil, 2010-2014

\begin{tabular}{|c|c|c|c|c|c|c|c|c|c|c|c|c|}
\hline \multirow[t]{2}{*}{ Indicators } & \multicolumn{6}{|c|}{ Pernambuco } & \multicolumn{6}{|l|}{ Brazil } \\
\hline & 2010 & 2011 & 2012 & 2013 & 2014 & $2014 / 2010$ & 2010 & 2011 & 2012 & 2013 & 2014 & $2014 / 2010$ \\
\hline \multicolumn{13}{|l|}{ Diagnosis and treatment } \\
\hline Tests performed ${ }^{\mathrm{b}}$ & 98,561 & 103,880 & 94,384 & 120,171 & 256,809 & 2.61 & $1,382,785$ & $1,267,247$ & 878,751 & 795,174 & 814,905 & 0.59 \\
\hline Positive result & 8186 & 7623 & 5336 & 6509 & 8713 & - & 69,436 & 59,946 & 38,685 & 36,994 & 33,193 & - \\
\hline Positivity (\%) & 8.31 & 7.34 & 5.65 & 5.42 & 3.39 & 0.41 & 5.02 & 4.73 & 4.4 & 4.65 & 4.07 & 0.81 \\
\hline Treated & 6500 & 6027 & 4300 & 5197 & 7104 & - & 61,820 & 52,238 & 29,506 & 28,272 & 26,042 & - \\
\hline Treatment (\%) & 79.4 & 79.1 & 80.6 & 79.8 & 81.5 & 1.03 & 89.0 & 87.1 & 76.3 & 76.4 & 78.5 & 0.88 \\
\hline \multicolumn{13}{|l|}{ Hospitalizations } \\
\hline $\begin{array}{l}\text { Hospitalizations due to } \\
\text { schistosomiasis }\end{array}$ & 78 & 62 & 53 & 33 & 41 & - & 301 & 240 & 218 & 163 & 175 & - \\
\hline $\begin{array}{l}\text { Hospitalization rate } \\
\text { (per 100,000 inhab.) }\end{array}$ & 0.89 & 0.70 & 0.59 & 0.36 & 0.44 & 0.50 & 0.16 & 0.12 & 0.11 & 0.08 & 0.09 & 0.55 \\
\hline \multicolumn{13}{|l|}{ Mortality } \\
\hline $\begin{array}{l}\text { Schistosomiasis } \\
\text { deaths (B65) }\end{array}$ & 196 & 174 & 158 & 141 & 140 & - & 514 & 546 & 488 & 468 & 480 & - \\
\hline Total deaths & 54,570 & 57,219 & 57,132 & 58,209 & 57,823 & - & $1,136,947$ & $1,170,498$ & $1,181,166$ & $1,210,474$ & $1,227,039$ & - \\
\hline $\begin{array}{l}\text { Proportional } \\
\text { schistosomiasis } \\
\text { mortality (\%) }\end{array}$ & 0.36 & 0.30 & 0.28 & 0.24 & 0.24 & 0.67 & 0.05 & 0.05 & 0.04 & 0.04 & 0.04 & 0.87 \\
\hline $\begin{array}{l}\text { Schistosomiasis } \\
\text { mortality rate } \\
\text { (per 100,000 inhab.) }^{\text {a }}\end{array}$ & 2.23 & 1.96 & 1.77 & 1.53 & 1.51 & 0.68 & 0.27 & 0.28 & 0.25 & 0.23 & 0.24 & 0.88 \\
\hline
\end{tabular}

${ }^{a}$ Total population - Pernambuco, 2010: 8796032, 2011: 8864906, 2012: 8931028, 2013: 9208550, 2014: 9277727; Brazil: 2010: 190747855, 2011: 192379287, 2012: 193946886, 2013: 201032714, 2014: 202768562

bPopulation accessed - Pernambuco, 2010: 137363, 2011: 140503, 2012: 133990, 2013: -, 2014: 358954; Brazil, 2010: 1849983, 2011: 1709702, 2012: 1205789, 2013: 1111304, 2014: 1127632 
this. A diagnosis of schistosomiasis at some time in life was reported by $17.1 \%$ of the interviewees (Please see Table 2).

The highest schistosomiasis prevalence among all four regions was found in the forest area (Zona da Mata) $(2.8 \%, p=0.001)$. The schistosomiasis prevalence in areas with two treatment cycles was 30\% lower than that in areas with just one treatment cycle $(p=0.011)$. Individuals who lived in homes that flooded, were of economic status E, were male, were aged 15-44, stated that their skin color was black or brown, and had current and past contact with river water presented a higher prevalence of schistosomiasis. Of the interviewees, $17.1 \%$ stated that they had been diagnosed with schistosomiasis at some time in their lives (Please see Table 2). Those who had had the disease stated that the main symptoms were abdominal pain $(47 \%)$ and feeling sick (35\%).

The schistosomiasis prevalence in areas with two treatment cycles was approximately $35 \%$ lower than that in locations with just one treatment cycle, even after the adjustments (Please see Table 3).

Generally, before treatment, $64.4 \%$ of the locations had schistosomiasis prevalence rates of between 10 and $19.9 \%$, whereas $31.4 \%$ had prevalence rates of $20 \%$ or greater. In areas with one and two treatment cycles, this proportion decreased to $13.1 \%$ and $5.4 \%$, respectively. More robust reductions were found in the southern and northern regions than in the other regions. After two cycles of collective treatment, $64.3 \%$ of the locations studied had a schistosomiasis prevalence equal to zero (Please see Fig. 1). The average schistosomiasis prevalence was $18.6 \%$ at baseline, decreasing to $4.1 \%$ and $2.0 \%$ in areas with one and two treatment cycles, respectively (Please see Fig. 2).

\section{Discussion}

SANAR provide a tested example for Brazil to compose its response to Sustainable Development Goals (SDGs). For the first time, the global agenda faces the explicit challenge to end epidemics of neglected tropical diseases by 2030 , among other targets related to Goal 3: ensure healthy lives and promote well-being for all at all ages [31].

Repeated treatment during childhood and adolescence persists into adulthood, reducing the chronic evolution of schistosomiasis in hyperendemic areas, thus increasing the quality of life. Accurate monitoring in the next decade is essential to control not only the morbidity but also the mortality and severity of the disease, strengthening the effect of large-scale preventive chemotherapy regimens [32].

SANAR has provided new protocols and strategies for health surveillance actions for schistosomiasis in the state of Pernambuco, emphasizing the relevance of neglected tropical diseases in the political agenda of the state government. The overall cost of specific interventions for schistosomiasis to the state government, including the actions of the SANAR Program, was approximately US\$308,081 in the period from 2011 to 2014, or about US\$ 6000 per month; these expenses included inputs, printed matter, equipment, personnel wages, consultancies, training, and fuel. Through the Integrated Strategic Action Plan for the Elimination of Neglected Diseases, the Ministry of Health freely delivers praziquantel to the municipalities to guarantee collective treatment in the priority areas [4]. Unfortunately, the country's current political scenario of funding restrictions on health policies for the next 20 years is threatening the program's sustainability [33].

In keeping with the global trend of reduced schistosomiasis occurrence, which was estimated to be $23.5 \%$ between 2005 and 2015 [1], the detection of positive cases was found to have decreased in Brazil as a whole and in Brazilian states with high endemicity such as Pernambuco [11]. When the secondary data were used to analyze the timespan from 2010 to 2014 in Pernambuco, the reduction was significantly greater than that in Brazil and in the states of Sergipe and Alagoas (two states neighboring Pernambuco with similar schistosomiasis endemicity) [5]. The success achieved in controlling schistosomiasis in Pernambuco, compared to that achieved in the national and regional context, can essentially be attributed to the SANAR Program, which has not yet been implemented in the country's other states. The possibility of comparing Pernambuco's results with those achieved in Brazil as a whole and in neighboring states is a natural experiment [34]. An important part of the achievement attains plausibility via the adoption of collective treatment in locations with a prevalence greater than $10 \%$, as recommended by the WHO [15], instead of the implementation of the Brazilian Ministry of Health's recommendation, which is based on a prevalence of greater than $25 \%$ as the cutoff point for collective interventions [4].

When the primary data related to the biological material collected was evaluated, a beneficial effect of collective treatment was found in the reduction of positive schistosomiasis cases in hyperendemic locations. After two treatment cycles had been performed, approximately nine of every ten locations had a schistosomiasis prevalence of $<10 \%$, the limit defined by the WHO as a low community risk for the propagation of the disease [35].

The finding that a higher number of treatment cycles had a protective effective on schistosomiasis occurrence in priority locations in Pernambuco reinforces the ability to control the disease in hyperendemic locations by means of collective treatment integrated with primary health care service actions, particularly the Family 
Table 2 Sample characteristics, schistosomiasis prevalence and raw analysis according to independent variables. Pernambuco, Brazil, 2014

\begin{tabular}{|c|c|c|c|c|c|c|c|}
\hline \multirow{3}{*}{$\begin{array}{l}\text { Variables } \\
\text { Number of treatment cycles }\end{array}$} & \multirow[t]{3}{*}{$\mathrm{n}$} & \multirow[t]{2}{*}{$\%$} & \multirow{2}{*}{$\begin{array}{l}\% \\
\text { Schistosomiasis }\end{array}$} & \multicolumn{3}{|c|}{ Raw analysis } & \multirow[t]{2}{*}{$p$-value } \\
\hline & & & & $\mathrm{PR}$ & $95 \% \mathrm{C}$ & & \\
\hline & & & & & & & 0.011 \\
\hline 1 & 3963 & 44.4 & 2.7 & 1.00 & & & \\
\hline 2 & 4969 & 55.6 & 1.9 & 0.70 & 0.53 & 0.92 & \\
\hline Region & & & & & & & 0.001 \\
\hline Northern (Agreste Setentrional) & 2415 & 27.0 & 1.2 & 1.00 & & & \\
\hline Metropolitan & 2400 & 26.9 & 2.5 & 2.12 & 1.37 & 3.28 & \\
\hline Southern (Agreste Meridional) & 1290 & 14.4 & 2.1 & 1.74 & 1.04 & 2.93 & \\
\hline Forest area (Zona da mata) & 2827 & 31.7 & 2.8 & 2.36 & 1.55 & 3.59 & \\
\hline Zone of residence & & & & & & & 0.105 \\
\hline Urban & 4878 & 55.0 & 2.4 & 1.00 & & & \\
\hline Rural & 3992 & 45.0 & 1.9 & 0.79 & 0.60 & 1.05 & \\
\hline Open drainage ditch/sewer & & & & & & & 0.999 \\
\hline No & 5168 & 58.9 & 2.2 & 1.00 & & & \\
\hline Yes & 3614 & 41.2 & 2.2 & 1.00 & 0.75 & 1.33 & \\
\hline Was there an open drainage ditch/sewer that was corrected after $2011 ?$ & & & & & & & 0.860 \\
\hline No & 8535 & 97.2 & 2.2 & 1.00 & & & \\
\hline Yes & 247 & 2.8 & 2.0 & 0.92 & 0.38 & 2.23 & \\
\hline Does water usually flood houses? & & & & & & & 0.039 \\
\hline Yes & 981 & 11.2 & 2.8 & 1.00 & & & \\
\hline No & 5380 & 61.3 & 2.4 & 0.86 & 0.57 & 1.30 & \\
\hline There has never been a flood & 2417 & 27.5 & 1.6 & 0.57 & 0.35 & 0.93 & \\
\hline Was there flooding, but the situation improved after 2011? & & & & & & & 0.114 \\
\hline No & 8505 & 96.9 & 2.3 & 1.00 & & & \\
\hline Yes & 273 & 3.1 & 0.7 & 0.33 & 0.08 & 1.31 & \\
\hline Economic status & & & & & & & 0.001 \\
\hline$B$ and $C$ & 2739 & 33.5 & 2.3 & 1.00 & & & \\
\hline D & 4801 & 58.8 & 2.0 & 0.86 & 0.63 & 1.19 & \\
\hline $\mathrm{E}$ & 626 & 7.7 & 4.3 & 1.91 & 1.22 & 2.97 & \\
\hline Sex & & & & & & & 0.020 \\
\hline Female & 4860 & 54.4 & 1.9 & 1.00 & & & \\
\hline Male & 4072 & 45.6 & 2.6 & 1.39 & 1.05 & 1.83 & \\
\hline Age (full years) & & & & & & & 0.002 \\
\hline$<5$ & 738 & 5.7 & 0.6 & 1.00 & & & \\
\hline $5-14$ & 2746 & 21.2 & 1.6 & 2.42 & 0.74 & 7.91 & \\
\hline $15-44$ & 6335 & 48.9 & 2.8 & 4.35 & 1.39 & 13.6 & \\
\hline 45 or over & 3145 & 24.2 & 2.0 & 3.11 & 0.97 & 9.96 & \\
\hline Skin color & & & & & & & 0.021 \\
\hline White & 2443 & 27.5 & 1.5 & 1.00 & & & \\
\hline Black & 848 & 9.5 & 3.2 & 2.10 & 1.29 & 3.43 & \\
\hline Brown & 5546 & 62.3 & 2.4 & 1.57 & 1.09 & 2.26 & \\
\hline Yellow/indigenous & 63 & 0.7 & 1.6 & 1.05 & 0.15 & 7.52 & \\
\hline Lives with a partner & & & & & & & 0.421 \\
\hline
\end{tabular}


Table 2 Sample characteristics, schistosomiasis prevalence and raw analysis according to independent variables. Pernambuco, Brazil, 2014 (Continued)

\begin{tabular}{|c|c|c|c|c|c|c|c|}
\hline \multirow[t]{2}{*}{ Variables } & \multirow[t]{2}{*}{$n$} & \multirow[t]{2}{*}{$\%$} & \multirow{2}{*}{$\begin{array}{l}\% \\
\text { Schistosomiasis }\end{array}$} & \multicolumn{3}{|c|}{ Raw analysis } & \multirow[t]{2}{*}{$p$-value } \\
\hline & & & & $\mathrm{PR}$ & $95 \% \mathrm{Cl}$ & & \\
\hline No & 4832 & 54.1 & 2.1 & 1.00 & & & \\
\hline Yes & 4100 & 45.9 & 2.3 & 1.12 & 0.85 & 1.48 & \\
\hline Has contact with water from rivers & & & & & & & $<0.001$ \\
\hline No, never & 2263 & 25.6 & 1.1 & 1.00 & & & \\
\hline Yes, in the past but not currently & 4046 & 45.7 & 2.6 & 2.30 & 1.49 & 3.56 & \\
\hline Yes, currently & 2537 & 28.7 & 2.7 & 2.46 & 1.56 & 3.88 & \\
\hline Has contact with water from open drainage ditches/sewers & & & & & & & 0.627 \\
\hline No, never & 4180 & 47.3 & 2.2 & 1.00 & & & \\
\hline Yes, in the past but not currently & 1705 & 19.3 & 2.5 & 1.11 & 0.77 & 1.59 & \\
\hline Yes, currently & 2950 & 33.4 & 2.0 & 0.91 & 0.66 & 1.26 & \\
\hline Walks barefoot in the street & & & & & & & 0.999 \\
\hline Never & 5509 & 61.9 & 2.2 & 1.00 & & & \\
\hline Sometimes & 1714 & 19.3 & 2.2 & 1.01 & 0.70 & 1.45 & \\
\hline Nearly always & 526 & 5.9 & 2.3 & 1.04 & 0.58 & 1.87 & \\
\hline Always & 1154 & 13.0 & 2.2 & 0.99 & 0.64 & 1.51 & \\
\hline Has had schistosomiasis at some time in life & & & & & & & 0.193 \\
\hline No & 7107 & 82.9 & 2.1 & 1.00 & & & \\
\hline Yes & 1467 & 17.1 & 2.7 & 1.26 & 0.89 & 1.78 & \\
\hline
\end{tabular}

Health Strategy [36, 37]. Although socioenvironmental changes are one of the most important determinants of schistosomiasis [13, 37], few such changes occurred during the period of the SANAR Program activities [21], thus reducing the possibility that an environmental effect explains the reduction in schistosomiasis prevalence.

Table 3 Raw and adjusted analyses of the association between schistosomiasis and medication treatment cycle. Pernambuco, Brazil, 2014

\begin{tabular}{llll}
\hline & \multicolumn{2}{l}{ Treatment cycle $^{\mathrm{a}}$} & p-value \\
\cline { 2 - 3 } & $\mathrm{PR}$ & $95 \% \mathrm{Cl}$ & 0.011 \\
\hline Raw analysis & 0.70 & $0.53-0.92$ & 0.005 \\
Adjustment 1 & 0.64 & $0.47-0.87$ & 0.001 \\
Adjustment 2 & 0.58 & $0.42-0.81$ & 0.002 \\
Adjustment 3 & 0.61 & $0.44-0.83$ & 0.008 \\
\hline Adjustment 4 & 0.65 & $0.47-0.89$ & \\
\hline
\end{tabular}

${ }^{a}$ Reference group: 1st treatment cycle; Exposed group: 2nd treatment cycle Adjustment 1: region of the state and zone of residence

Adjustment 2: Adjustment $1+$ positive house flooding status and economic status (ABEP)

Adjustment 3: Adjustment $2+$ sex, age and skin color

Adjustment 4: Adjustment $3+$ contact with river water + schistosomiasis at some time in life

$P R$ prevalence ratio. 95\% Cl 95\% confidence interval. $p$-value: Wald's heterogeneity test
In terms of health impacts and cost-effectiveness, few interventions rival collective treatment of neglected diseases integrated with primary health care. In addition to its relevance for people with schistosomiasis, this treatment approach has been increasingly recognized for its beneficial effects on strengthening health systems and on economic development [38].

Despite the relevance of the finding regarding the effectiveness of the intervention spearheaded by the SANAR Program, the evidence also shows that collective treatment alone is not sufficient to eliminate the disease. The SANAR Program promoted the integration of collective actions with Pernambuco's primary health network, particularly with multidisciplinary family health teams. As the main expression of the Integrated Strategic Action Plan for the Elimination of Neglected Diseases in the state of Pernambuco, the SANAR Program intervention had a marked effect on increasing the number of people examined and treated between 2011 and 2014 [4].

The evidence from this study points to the relevance of continuing to monitor hyperendemic regions along with strengthening vector control and health services, the contribution of which to the effectiveness of the SANAR Program deserves to be evaluated in depth. 


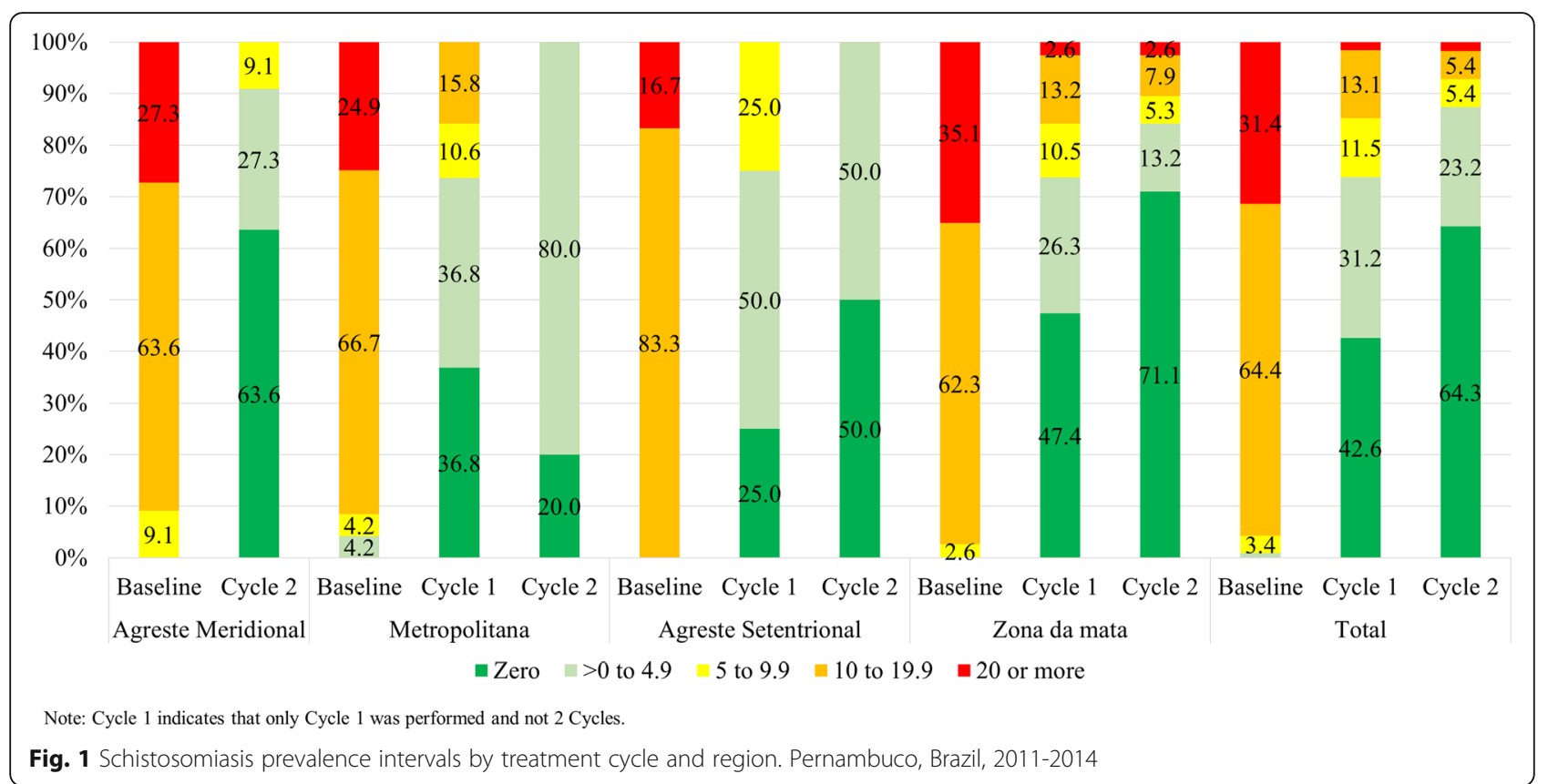

Nevertheless, it is essential to reaffirm the key nature of implementing substantial environmental improvements in order to permanently eliminate and/or control schistosomiasis, thus valuing the quality of life and dignity of the population and, even more importantly, addressing the social determinants of the problem [10, 13, 22, 37].

Some authors [12] suggest that environmental changes can be more feasible if funding for programs to address neglected diseases includes allocating part of the resources to health activities, including the purchase and distribution of medication, and allocating another part of the resources to investments in extending treated drinking water networks and adequate sanitation and in improving living conditions [37].

The relevance of the socioenvironmental determinants of the problem is reinforced by noting that the overall

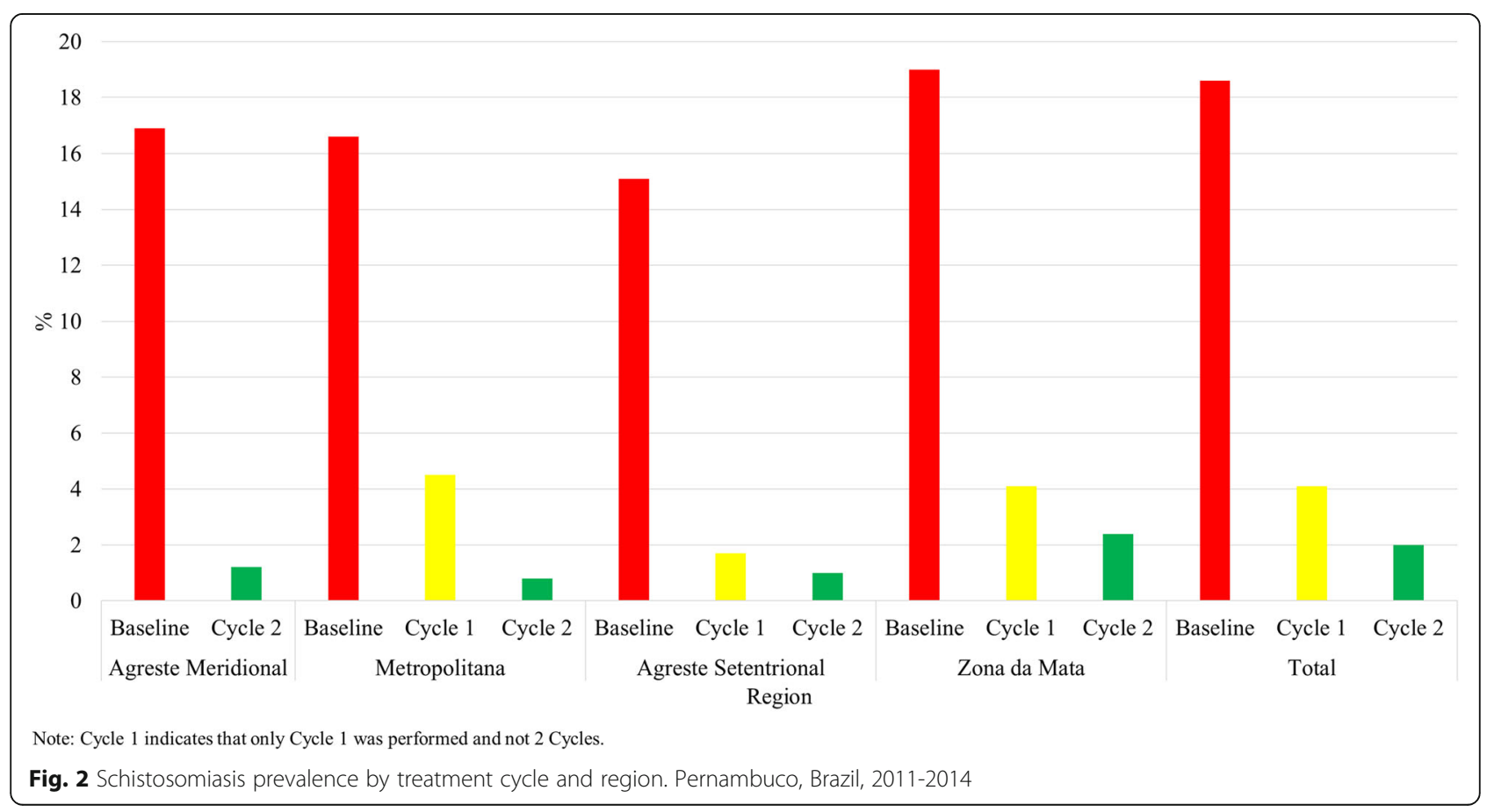


success of the SANAR Program did not overcome the geographical context. The findings indicate that coastal regions and regions near watercourses (forest area/Zona da Mata), continue to have the highest prevalence rates and have higher proportions of locations with prevalence rates above $10 \%$ than do other regions $[8,12]$.

Although the study included poor and vulnerable locations, socioeconomic differences were strongly associated with the occurrence of schistosomiasis, thus highlighting the relevance of accounting for the heterogeneity of the population, even in locations considered to be contextually similar.

Some limitations of this study need to be considered. First, it was not possible to select the same individuals before and after collective treatment, which may have diluted the effect of treatment. However, given the large differences found, we do not believe that this limitation influenced the results in a significant manner. Second, the use of the Kato-Katz method to diagnose schistosomiasis in areas of low endemicity has been questioned. Some authors suggest that more sensitive techniques, such as ELISA, should be used [26]. However, the prolonged presence of reactive IgM after treatment and the death of the worms is a critical problem in evaluating the effectiveness of an intervention. We suggest that more sensitive techniques be used in future studies in high endemicity areas that become low prevalence areas following collective treatment in order to monitor changes via the complementary use of more sensitive techniques such as serial stool tests. Another limitation is that schistosomiasis surveys in the untreated locations, which could be used as controls, were not conducted. Furthermore, information on the snail vectors and their infection status in the study area is lacking.

The SANAR Program demonstrated effectiveness in controlling schistosomiasis in areas with high endemicity, so its implementation in other regions of Brazil and across the world can be recommended via adopting collective treatment in areas with a positive test prevalence in $10 \%$ or more of the population. The integrated action of the SANAR Program with the Family Health Strategy augments the interaction of the effects arising from collective treatment, prevention, surveillance and selective treatment. Despite the short time during which the Program has been implemented, its benefits for the population go beyond the significant reduction in the number of individuals with positive schistosomiasis test results, extending to a reduction in hospitalization and mortality from this disease.

\section{Conclusions}

The political decision made in Pernambuco to implement the SANAR Program in 2011 greatly impacted the burden of schistosomiasis. The program promoted an effective reduction in the occurrence of schistosomiasis in hyperendemic areas in Pernambuco. The response was stronger in areas with two cycles of collective treatment than in one-cycle areas. The SANAR Program should be evaluated by other Brazilian states and even globally as a successful strategy for facing the challenge of neglected diseases.

\section{Abbreviations \\ 95\% Cl: 95\% confidence interval; PE: Pernambuco State; PR: Prevalence ratio; SANAR Program: Plan to Reduce and Eliminate Neglected Diseases; \\ SDG: Sustainable development goals; SIH-SUS: Hospital Information System; SIM: Mortality Information System; SINAN: Information System for Notifiable Diseases; SISPCE: Schistosomiasis Control Program Information System; \\ SISPCE/SES-PE: Schistosomiasis Control Program Information System of the Pernambuco State Government; WHO: World Health Organization \\ Funding \\ This research was supported by the Brazilian Ministry of Health, Health Surveillance Secretariat. The funders played no role in the design of the study; the collection, analysis, and interpretation of the data; the writing of the report; or the decision to submit the article for publication. The researchers were independent of influence from the funding agency.}

\section{Availability of data and materials}

Please contact the author Bruno Pereira Nunes - nunesbp@gmail.com - for data requests.

\section{Authors' contributions}

LAF, BPN and ET designed the study, monitored the data collection for the survey, analyzed the data, and drafted the first version of the paper. EF, JAMS and JBSJ designed the study as well as drafted and revised the manuscript. All authors read and approved the final manuscript.

\section{Ethics approval and consent to participate}

The Federal University of Pelotas Faculty of Medicine's Research Ethics Committee approved the project under number 772.632. All the subjects signed an informed consent form, and all were advised of their right to not participate as well as assured of the confidentiality of their individual data.

\section{Consent for publication}

Not applicable.

\section{Competing interests}

The authors declare that they have no competing interests.

\section{Publisher's Note}

Springer Nature remains neutral with regard to jurisdictional claims in published maps and institutional affiliations.

\section{Author details}

${ }^{1}$ Programa de Pós-Graduação em Epidemiologia, Universidade Federal de Pelotas, Pelotas, Brazil. ${ }^{2}$ Programa de Pós-Graduação em Enfermagem, Universidade Federal de Pelotas, Rua Gomes Carneiro, 1, Campus ANGLO, Centro, Pelotas, RS CEP: 96010-610, Brazil. ${ }^{3}$ Grupo de Estudos em Gestão e Avaliação em Saúde, Instituto de Medicina Integral Prof. Fernando Figueira, Recife, Pernambuco, Brazil. ${ }^{4}$ Instituto de Higiene e Medicina Tropical, Universidade NOVA de Lisboa, Lisboa, Portugal. ${ }^{5}$ Pan American Health Organization (PAHO/AMRO/WHO), Washington - DC, USA.

Received: 27 November 2017 Accepted: 8 October 2018

Published online: 25 October 2018

\section{References}

1. Vos T, Allen C, Arora M, Barber RM, Bhutta ZA, Brown A, Carter A, Casey DC, Charlson FJ, Chen AZ, et al. Global, regional, and national incidence, prevalence, and years lived with disability for 310 diseases and injuries, 1990-2015: a systematic analysis for the global burden of disease study 2015. Lancet. 2016;388(10053):1545-602. 
2. World Health Organization (WHO). Schistosomiasis: progress report 20012011 and strategic plan 2012-2020. Geneva: WHO Library; 2013. Available at: http://www.who.int/iris/handle/10665/78074

3. Zoni AC, Catalá L, Ault SK. Schistosomiasis prevalence and intensity of infection in Latin America and the Caribbean countries, 1942-2014: a systematic review in the context of a regional elimination goal. PLoS Negl Trop Dis. 2016;10(3)::0004493.

4. Brasil. Ministério da Saúde. Secretaria de Vigilância em Saúde. Departamento de Vigilância em Doenças Transmissíveis. Plano integrado de ações estratégicas de eliminação da hanseníase, filariose, esquistossomose e oncocercose como problema de saúde pública, tracoma como causa de cegueira e controle das geohelmintíases: plano de ação 2011-2015/ Ministério da Saúde, Secretaria de Vigilância em Saúde, Departamento de Vigilância em Doenças Transmissíveis. - Brasília: Ministério da Saúde, 2012. Available at: http://bvsms.saude.gov.br/bvs/publicacoes/plano_integrado_ acoes_estrategicas_2011_2015.pdf (in portuguese).

5. Brasil. Sistema de Informação do Programa de Controle da Esquistossomose. Sistema de Informação de Agravos em Saúde/2012. Casos confirmados de Esquistossomose, 1995 a 2011. Braślia (DF). 2012, Grandes Regiões e Unidades Federadas, Brasil. Available at: http://tabnet.datasus.gov. br/cgi/tabcgi.exe?sinannet/cnv/esquistobr.def (in portuguese).

6. Martins-Melo FR, Pinheiro MCC, Ramos AN Jr, Alencar CH. Bezerra FSdM, Heukelbach J. trends in schistosomiasis-related mortality in Brazil, 2000-2011. Int J Parasitol. 2014;44(14):1055-62.

7. Gomes Casavechia MT, de Melo GAN, Da Silva Fernandes ACB, De Castro KR, Pedroso RB, Da Silva ST, Teixeira JJV. Systematic review and metaanalysis on Schistosoma mansoni infection prevalence, and associated risk factors in Brazil. Parasitology. 2018:1-15.

8. Barreto AVMS, Melo ND, Ventura JVT, Santiago RT, Silva MBA. Analysis of schistosomiasis mansoni positivity in endemic health regions in the state of Pernambuco, Brazil, 2005-2010. Epidemiologia e Serviços de Saúde. 2015;24:87-96

9. Barbosa CS, Favre TC, Wanderley TN, Callou AC, Pieri OS. Assessment of schistosomiasis, through school surveys, in the Forest Zone of Pernambuco, Brazil. Mem Inst Oswaldo Cruz. 2006;101(supl.1):55-62.

10. Saucha CW, Silva JAM, Amorim LB. Basic sanitation conditions in schistosomiasis hyperendemic areas in Pernambuco state, Brazil, 2012. Epidemiologia e Serviços de Saúde. 2015;24:497-506.

11. Barbosa CS, de Souza Gomes EC, Campos JV, de Oliveira FJM, da Silva Mesquita MC, de Oliveira ECA, Domingues ALC. Morbidity of mansoni schistosomiasis in Pernambuco-Brazil: analysis on the temporal evolution of deaths, hospital admissions and severe clinical forms (1999-2014). Acta Trop. 2016:164:10-6.

12. Kloos H, Correa-Oliveira R, Oliveira Quites HF, Caetano Souza MC, Gazzinell A. Socioeconomic studies of schistosomiasis in Brazil: a review. Acta Trop. 2008;108(2-3):194-201.

13. Kloetzel K, de Azevedo Vergetti AM. Repeated mass treatment of schistosomiasis mansoni: experience in hyperendemic areas of Brazil. II. Micro-level evaluation of results. Ann Trop Med Parasitol. 1988;82(4):367-76.

14. Brasil, Ministério da Saúde, Secretaria de Vigilância em Saúde, Departamento de Vigilância Epidemiológica. Vigilância da Esquistossomose Mansoni: diretrizes técnicas. 4.ed. Brasília: Ministério da Saúde; 2014: 144p. Available at: http://bvsms.saude.gov.br/bvs/publicacoes/vigilancia_esquistossome_ mansoni_diretrizes_tecnicas.pdf (in portuguese).

15. World Health Organization (WHO). Preventive chemotherapy in human helminthiasis: coordinated use of anthelminthic drugs in control interventions: a manual for health professionals and programme managers. Geneva: World Health Organization; 2006. Available at: http://apps.who.int/ iris/bitstream/handle/10665/43545/9241547103_eng.pdf?sequence=1

16. Morgan JA, Dejong RJ, Snyder SD, Mkoji GM, Loker ES. Schistosoma mansoni and Biomphalaria: past history and future trends. Parasitology. 2001;123(Suppl):S211-28

17. Coeli R, Baba EH, Araujo N, Coelho PMZ, Oliveira G. Praziquantel treatment decreases Schistosoma mansoni genetic diversity in experimental infections. PLoS Negl Trop Dis. 2013;7(12):e2596.

18. World Health Organization (WHO). 10 facts about schistosomiasis. World Health Organization; 2016. Available at: http://www.who.int/features/ factfiles/schistosomiasis/en/ (online).

19. Secretaria Estadual de Saúde de Pernambuco. Secretaria Executiva de Vigilância em Saúde. Esquistossomose e Geo-Helmintíases: protocolo de apoio ao tratamento coletivo. Pernambuco, 2012. Available at: http://portal. saude.pe.gov.br/sites/portal.saude.pe.gov.br/files/protocolo_de_apoio_ao_ tratamento_coletivo-_esquistossomose.pdf (in portuguese).

20. Secretaria Estadual de Saúde de Pernambuco. Secretaria Estadual de Saúde. Secretaria Executiva de Vigilância em Saúde. Cadernos de Monitoramento Programa Sanar - Volume 1:Esquistossomose / Secretaria Estadual de Saúde. Secretaria Executiva de Vigilância em Saúde.- 1. ed. - Recife: Secretaria Estadual de Saúde, 2013. 23p. Available at: http://portal.saude.pe. gov.br/sites/portal.saude.pe.gov.br/files/caderno_de_monitoramento_ esquistossomose.pdf. (in portuguese).

21. Secretaria Estadual de Saúde de Pernambuco. Secretaria Executiva de Vigilância em Saúde. Esquistossomose e Geo-Helmintíases: relatório das condições de saneamento das áreas/localidades hiperendêmicas em Pernambuco. 2. ed. Recife: Secretaria Estadual de Saúde; 2013. Available at: (http://portal.saude.pe.gov.br/sites/portal.saude.pe.gov.br/files/relatorio_das_ condicoes_de_saneamento_das_localidades_hiperendemicas_em_pe.pdf. (in portuguese).

22. Secretaria Estadual de Saúde de Pernambuco. Secretaria Executiva de Vigilância em Saúde. Coordenação do Programa SANAR. Esquistossomose: guia operacional para a redução em Pernambuco. Pernambuco, 2012. (in portuguese).

23. Secretaria Estadual de Saúde de Pernambuco. Secretaria Executiva de Vigilância em Saúde. Programa de Enfretamento das Doenças Negligenciadas no Estado de Pernambuco/SANAR - 2011-2014 [Internet]. 2. ed. Recife: Secretaria Estadual de Saúde; 2013. Available at: http://portal. saude.pe.gov.br/sites/portal.saude.pe.gov.br/files/plano_sanar_2011-2014.pdf. (in portuguese).

24. Secretaria Estadual de Saúde de Pernambuco. Secretaria Executiva de Vigilância em Saúde. SISPCE: Guia de apoio operacional ao Sistema de Informação do Programa de Controle da Esquistossomose para os munípios do estado de Pernambuco. Pernambuco, 2012. Available at: http://portal. saude.pe.gov.br/sites/portal.saude.pe.gov.br/files/esquistossomose_-_guia_ sispce_.pdf. (in portuguese).

25. Katz N, Coelho PM, Pellegrino J. Evaluation of Kato's quantitative method through the recovery of Schistosoma mansoni eggs added to human feces. J Parasitol. 1970;56(5):1032-3.

26. Espirito-Santo MC, Alvarado-Mora MV, Pinto PL, Sanchez MC, Dias-Neto E, Castilho VL, Goncalves EM, Chieffi PP, Luna EJ, Pinho JR, et al. Comparative study of the accuracy of different techniques for the laboratory diagnosis of schistosomiasis Mansoni in areas of low Endemicity in Barra Mansa City, Rio de Janeiro state. Brazil BioMed research international. 2015;2015:135689.

27. World Health Organization (WHO) Expert Committee on the Control of Schistosomiasis. Prevention and control of schistosomiasis and soil-transmitted helminthiasis: report of a WHO expert committee. Geneva: World Health Organization; 2002. Available at: http://apps.who.int/iris/bitstream/handle/ 10665/42588/WHO_TRS_912.pdf?sequence=1\&isAllowed=y

28. Martin LK, Beaver PC. Evaluation of Kato thick-smear technique for quantitative diagnosis of helminth infections. The American journal of tropical medicine and hygiene. 1968;17(3):382-91.

29. Katz N, Chaves A, Pellegrino J. A simple device for quantitative stool thicksmear technique in schistosomiasis mansoni. Revista do Instituto de Medicina Tropical de Sao Paulo. 1972;14(6):397-400.

30. Barros AJ, Hirakata VN. Alternatives for logistic regression in cross-sectional studies: an empirical comparison of models that directly estimate the prevalence ratio. BMC Med Res Methodol. 2003;3(1):21.

31. United Nations. Transforming our world: the 2030 agenda for sustainable development a/RES/70/1. New York: United Nations; 2015. Available at: http://www.un.org/en/development/desa/population/migration/ generalassembly/docs/globalcompact/A_RES_70_1_E.pdf

32. World Health Organization (WHO). Report of an Informal Consultation on Schistosomiasis Control. Geneva: World Health Organization; 2011. Available at: http://apps.who.int/iris/bitstream/handle/10665/78066/9789241505017_ eng.pdf? sequence $=1$

33. Gomes EC, Leal-Neto OB, de Oliveira FJ Jr, Campos JV, Souza-Santos R, Barbosa CS. Risk analysis for occurrences of schistosomiasis in the coastal area of Porto de Galinhas, Pernambuco. Brazil BMC infectious diseases. 2014;14:101

34. Craig P, Katikireddi SV, Leyland A, Popham F. Natural experiments: an overview of methods, approaches, and contributions to public health intervention research. Annu Rev Public Health. 2017;38:39-56.

35. World Health Organization (WHO). Preventive chemotherapy: planning, requesting medicines, and reporting. Health Section of the Secretariat of 
the League of Nations. 2014;89(8):61-71 Available at: http://apps.who.int/ iris/bitstream/handle/10665/242179/WER8908_61-71.PDF?sequence= $1 \&$ isAllowed=y

36. Atun R, de Jongh $\mathrm{T}$, Secci F, Ohiri K, Adeyi O. A systematic review of the evidence on integration of targeted health interventions into health systems. Health Policy Plan. 2010;25(1):1-14.

37. Spiegel JM, Dharamsi S, Wasan KM, Yassi A, Singer B, Hotez PJ, Hanson C, Bundy DAP. Which new approaches to tackling neglected tropical diseases show promise? PLoS Med. 2010;7(5):e1000255.

38. Hotez PJ, Kamath A. Neglected tropical diseases in sub-Saharan Africa: review of their prevalence, distribution, and disease burden.

PLoS Negl Trop Dis. 2009;3(8):e412.

Ready to submit your research? Choose BMC and benefit from:

- fast, convenient online submission

- thorough peer review by experienced researchers in your field

- rapid publication on acceptance

- support for research data, including large and complex data types

- gold Open Access which fosters wider collaboration and increased citations

- maximum visibility for your research: over $100 \mathrm{M}$ website views per year

At BMC, research is always in progress.

Learn more biomedcentral.com/submissions 